\title{
Decomposition of Chlorinated Volatile Organic Compound by Metal Catalytic Incineration
}

\author{
Chih Ming Ma, Gui Bing Hong, and Chang Tang Chang
}

\begin{abstract}
In this study, the oxy-DE chlorination of 1 , 2-dichloroethane with excess oxygen fuels was performed in laboratory scale tubular reactor with packed $\mathrm{Pt}$ and $\mathrm{Fe}_{2} \mathrm{O}_{3}$ catalyst. It is important to understand the influence of operation parameters, such as catalysts, temperature, and retention time on removal efficiency. The catalysts, including noble metal catalyst $(\mathrm{Pt})$ and metal support catalyst $\left(\mathrm{Fe}_{2} \mathrm{O}_{3}\right)$, were used in this experiment. Additionally, the temperature and retention time were operated from $450^{\circ} \mathrm{C}$ to $650^{\circ} \mathrm{C}$ and from 0.3 to $1.5 \mathrm{~s}$, respectively. Reactants and products were analyzed quantitatively by gas chromatography with a flame ionization detector (GC/FID) and Mass Spectrometer (GC-MS). In order to evaluate the oxidation kinetic behavior of 1, 2-dichloroethane with $\mathrm{Pt}$ and $\mathrm{Fe}_{2} \mathrm{O}_{3}$ catalyst, the Arrhenius equation was used in this study. The experimental data were compared with those predicted results from the kinetic model. The results showed that the removal efficiency was relative to intermediate, final product profiles, retention time, and temperature. Furthermore, the optimum operation conditions of the reactor with $\mathrm{Pt}$ catalyst and $\mathrm{Fe}_{2} \mathrm{O}_{3}$ catalyst were determined.
\end{abstract}

Index Terms-Volatile organic compound, dichloromethane, metal catalyst.

\section{INTRODUCTION}

Volatile organic compounds (VOCs) are defined as the organic compounds that have high vapor pressure and are easily vaporized at ambient temperature and pressure. Halogenated VOCs emissions are associated with a wide range of industrial processes. For instance, dichloromethane is mainly used in metal degreasing processes and known to be hazardous to the environment and public health. Treatment of environmental pollution caused by Cl-VOC (e.g. dichloromethane, 1,2-dichloroethane) emissions has become an important topic recently [1]. Methods usually used to abate VOCs include incineration with or without catalyst, adsorption, absorption, and condensation. Among these methods, thermal incineration and catalytic incineration are the most effective control technologies [2]. Thermal incineration requires temperatures in excess of $750^{\circ} \mathrm{C}$, with the attendant disadvantages of high fuel cost and production of undesirable by-products. Catalytic incineration requires lower temperatures within the range of $200-500^{\circ} \mathrm{C}$ effectively to remove CL-VOCs [3].

Manuscript received January 4, 2013; revised March 4, 2013.

Chih Ming Ma and Gui Bing Hong are with the Department of Cosmetic Application and Management, St. Mary's Medicine Nursing and Management College, No. 100, Lane 265, San-Shing Rd., Sec. 2, San-Shing Shiang, Yi-Lan 266, Taiwan.

Chang Tang Chang is with the Department of Environmental Engineering, National I-Lan University, No. 1, Sheen-Long Road, I-Lan, 260, Taiwan (e-mail: ctchang@niu.edu.tw)
Recently, catalytic incineration has being attracted due to its lower reaction temperature, energy efficiency, and low NOx formation. Catalysts reported for oxidation of chlorinated VOCs consist of base metal oxides and noble metals with acidic supports [4]-[6]. Pope et al. [7] used a Pt catalyst catalytically to convert n-butanal in the mixture with methyl mercaptan. They have found that the conversion of n-butanal was suppressed by methyl mercaptan if operating temperature was below $300^{\circ} \mathrm{C}$. Besides, Chu and Lee [8] used a $\mathrm{Pt} / \mathrm{Al}_{2} \mathrm{O}_{3}$ catalyst to convert ethanol in mixtures with dimethyl disulfide. They found out that the conversion of ethanol was significantly suppressed by existence of $\left(\mathrm{CH}_{3}\right)_{2} \mathrm{~S}_{2}$ by temperature lower than $300^{\circ} \mathrm{C}$. Barbosa et al. [9] noted the activity of $\mathrm{Fe}_{2} \mathrm{O}_{3}$ supported on silica for total combustion to $\mathrm{CO}_{2}$ when iron content reached values above a certain level, and showed existence of a linear dependence of the rate of methane oxidation on total iron content of catalyst. By the way, SOx, and NOx reduction, PM (particulate matter) oxidation and wastewater treatment will be carried out over different type catalysts [10]-[15]. There is very few information about the study of combustion of chlorinated VOCs over base metal oxides [16]-[18]. On the other hand, base metal oxides are much less expensive and allow higher catalyst loading. Higher catalyst loading will bring to higher active surface area in metal oxide [19]. Although very active, the application of catalyst is using to low operating temperatures because of volatile formation and toxic chromium oxy-chloride. [1].

This study we also notice that function of the oxy-dechlorination of 1, 2-dichloroethane with excessive oxygen was carried out during laboratory scale tubular reactor with packed $\mathrm{Pt}$ and $\mathrm{Fe}_{2} \mathrm{O}_{3}$ catalyst. Spivey [3] indicated that those major parameters affecting catalytic incineration of VOCs included catalyst type, VOC speciation, VOCs concentration, operating temperature, space velocity and $\mathrm{O}_{2}$ concentration. In order to understand importance and influence of operating parameters on degradation of 1, 2-dichloroethane, the catalyst characteristics were examined first. Related kinetic equations were also established based on observed experimental results. The catalytic reaction of 1, 2-dichloroethane over Pt and $\mathrm{Fe}_{2} \mathrm{O}_{3}$ catalyst was fulfilled in continuous scale catalytic incinerator for this study. Present work, the kinetic model of Arrhenius was used to analyze the results. The results show that the Arrhenius model is suitable for predicting the kinetic behavior of 1,2-dichloroethane catalytic incineration. These results suggest that the adsorption of VOCs or $\mathrm{O}_{2}$ molecule is important in the process of catalytic incineration of 1 , 2-dichloroethane.Additionally, the optimum operating conditions in reactor with $\mathrm{Pt}$ catalyst and $\mathrm{Fe}_{2} \mathrm{O}_{3}$ catalyst were 
also defined in this study.

\section{MATERIALS AND METHODS}

\section{A. Preparation of Catalyst}

The first to prepare the catalyst is to preheat $700 \mathrm{~mL} \mathrm{H}_{2} \mathrm{O}$ to $70{ }^{\circ} \mathrm{C}$ in an oven. An aqueous solution will be obtained by adding $35 \mathrm{~g} \mathrm{Fe}_{2} \mathrm{O}_{3}$ and $14.2 \mathrm{~g} \mathrm{FeO}$, immediately followed by precipitation with an ammonia solution $(45 \mathrm{~mL})$. The precipitate was filtered off, washed and dried at $105^{\circ} \mathrm{C}$ for 12 h. Prior to the catalytic runs, the catalysts were thermally activated in air at $500{ }^{\circ} \mathrm{C}$ for 60 minutes. The commercial catalyst (DASH-220N Pt/ $/ \mathrm{Al}_{2} \mathrm{O}_{3}$ ) was used to compare the 1,2-dichloroethane treatment performance with the prepared catalyst in this study. The basic properties of DASH-220N $\mathrm{Pt} / \mathrm{Al}_{2} \mathrm{O}_{3}$ catalyst are shown in Table I.

\section{B. Experimental lnstruments}

The catalytic incineration of this study was preformed in a bench scale fixed bed reactor, as shown in Fig. 1. The system is divided into three parts: VOC gas system, catalytic incineration system, and effluent gas analyzing system. The gas generation system was composed of an Argon cylinder $(99.9 \%$, San Fu), an oxygen cylinder $(99.9 \%$, San Fu), three mass flow meters (Teledyne Hasting-Raydist, HFC-202), a water bath and a 1,2- dichloroethane generator (Pyrex). The temperature of simulated gas was measured by $\mathrm{K}$ type thermocouples before going through the catalytic reactor. The material as pipes, valves, regulators or fittings used was either SS-316 or Teflon. The catalytic incineration system was composed of a custom-made SS-316 tube reactor and a high temperature heater. The catalysts were set in the center of quartz tube and length, internal diameter, and outer diameter of the reactor were $400 \mathrm{~mm}, 15 \mathrm{~mm}$ and $24 \mathrm{~mm}$, respectively. Furthermore, the gas analysis system was composed of gas chromatograph with FID (HP5890II) and MS (Finnigan TRACE GC2000/TRACE MS) detectors.

\section{RESULTS AND DISCUSSION}

\section{A. Effect of Various Conditions}

In this study, three sets of experiments were performed to compare degradation efficiency of 1,2-dichloroethane with Equation (1).

$$
\text { Degradation efficiency }=1-\left[\mathrm{C}_{2} \mathrm{H}_{4} \mathrm{Cl}_{2}\right] /\left[\mathrm{C}_{2} \mathrm{H}_{4} \mathrm{Cl}_{2}\right]_{0}
$$

where $\left[\mathrm{C}_{2} \mathrm{H}_{4} \mathrm{Cl}_{2}\right]$ is the outlet concentration $(\mathrm{mol} / \mathrm{L}$ ) of 1,2dichloroethane and $\left[\mathrm{C}_{2} \mathrm{H}_{4} \mathrm{Cl}_{2}\right]_{0}$ is the inlet concentration (mol/ L) of 1,2- dichloroethane.

The degradation efficiency is a function of temperature and the results are shown in Fig. 2. No significant reduction of 1,2- dichloroethane (about 2 3\%) is attributed to temperature effects without using catalyst, case (a), in the incineration system. In case (b) of Fig. 2, the degradation efficiency was $30.2 \%$ at $\mathrm{T}=500^{\circ} \mathrm{C}$ with using packed $\mathrm{Fe}_{2} \mathrm{O}_{3}$ catalyst. However, the decomposition efficiency of 1,2dichloroethane was $78.2 \%$ at $500^{\circ} \mathrm{C}$ for case(c) (with $\mathrm{Pt}$ catalyst). Fig. 2 shows that the degradation efficiency of 1,2dichloroethane under various conditions following the sequence: Pt catalyst $>\mathrm{Fe}$ catalyst $>$ No catalyst in the incineration system.

TABLE I: THE BASIC PROPERTIES OF DASH-220N PT/AL $\mathrm{AL}_{2} \mathrm{O}_{3}$

\begin{tabular}{lllllll}
\hline Catalyst & Shape & $\begin{array}{l}\text { Bulk } \\
\text { density } \\
(\mathrm{g} / \mathrm{L})\end{array}$ & $\begin{array}{l}\text { Pore } \\
\text { volume } \\
\left(\mathrm{cm}^{3}\right. \\
\left.\mathrm{g}^{-1}\right)\end{array}$ & $\begin{array}{l}\text { BET } \\
\text { surface } \\
\text { area } \\
\left(\mathrm{m}^{2} \mathrm{~g}^{-1}\right)\end{array}$ & $\begin{array}{l}\text { Average } \\
\text { pore } \\
\text { radius } \\
(\mathrm{A})\end{array}$ & $\begin{array}{l}\text { Average } \\
\text { diameter } \\
(\mathrm{mm})\end{array}$ \\
\hline $\begin{array}{l}\mathrm{Pt} / \\
\mathrm{Al}_{2} \mathrm{O}_{3}\end{array}$ & Pellet & 770 & 0.44 & 166.62 & 76.12 & 0.44 \\
\hline
\end{tabular}

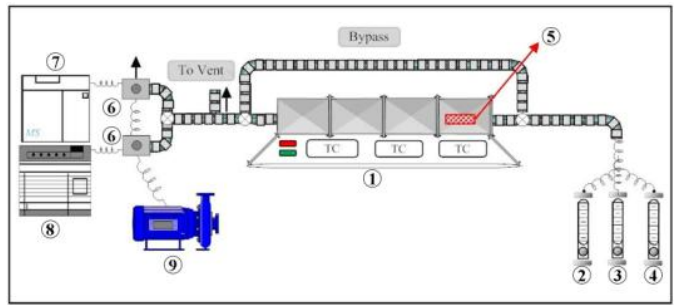

Fig. 1. A schematic diagram of a bench-scale catalytic incinerator (experimental instruments : 1 . high temperature reactor; 2. 1-2-dichloroethane generator; 3. oxygen cylinder; 4. argon cylinder; 5. catalyst; 6. six- port valve; 7. GC-ms; 8. GC-fid; 9. pump)

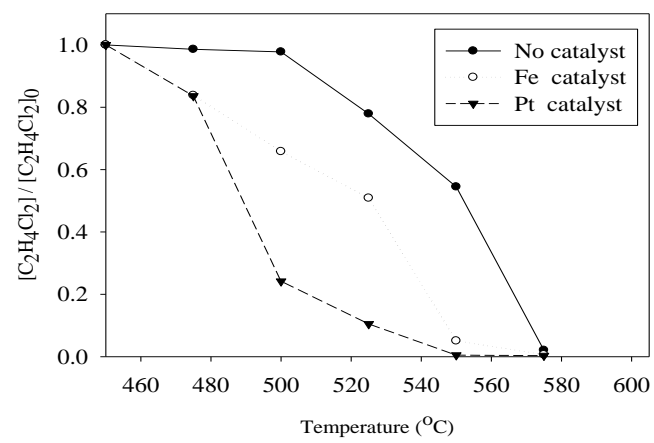

Fig. 2. Control efficiency of 1, 2-dichloroethane under various conditions. (Experimental conditions: case (a): no catalyst; case (b): Fe2O3 catalyst; and case (c): Pt catalyst in the incinerator at the retention time of 1.0s.)

\section{B. The Composition of Products}

Fig. 3 shows 1, 2- dichloroethane was oxidized over the $\mathrm{Pt}$ and $\mathrm{Fe}_{2} \mathrm{O}_{3}$ catalyst. The experiment shows that the conversion is increased rapidly at $550^{\circ} \mathrm{C}$, and the decomposed products of 1, 2- dichloroethane are $\mathrm{C}_{2} \mathrm{H}_{4}, \mathrm{C}_{2} \mathrm{H}_{6}$ and $\mathrm{C}_{3} \mathrm{H}_{8}$. Fig. 3(a) shows that the concentration of $\mathrm{C}_{2} \mathrm{H}_{6}$ and $\mathrm{C}_{3} \mathrm{H}_{8}$ is increased with the increasing of $\mathrm{C}_{2} \mathrm{H}_{4}$ concentration. The concentration of $\mathrm{C}_{2} \mathrm{H}_{6}$ is also increased with the increasing of $\mathrm{C}_{3} \mathrm{H}_{8}$ concentration but there is no relation to $\mathrm{C}_{2} \mathrm{H}_{4}$ for case (b) in Fig. 3. The maximum concentration of $\mathrm{C}_{2} \mathrm{H}_{6}$ and $\mathrm{C}_{3} \mathrm{H}_{8}$ with $\mathrm{Pt}$ catalyst and $\mathrm{C}_{2} \mathrm{H}_{4}$ with $\mathrm{Fe}_{2} \mathrm{O}_{3}$ was observed at retention time $0.7 \mathrm{sec}$.

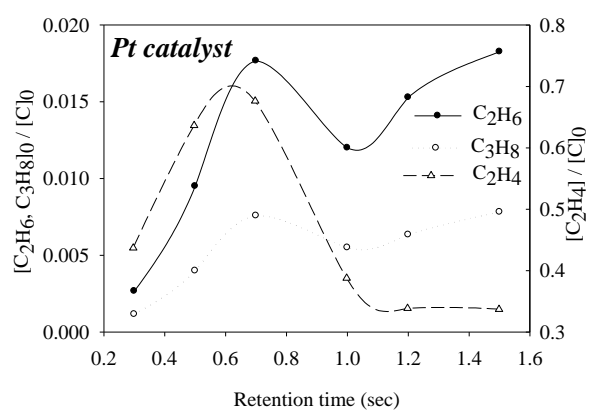

Fig. 3 (a). Products of 1, 2-dichloroethane decomposition over Pt catalyst of $550^{\circ} \mathrm{C}$. 


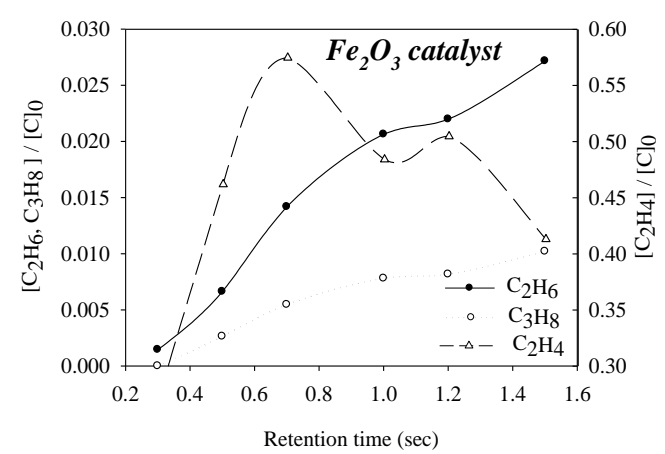

Fig. 3(b). Products of 1, 2-dichoroethane decomposition over $\mathrm{Fe}_{2} \mathrm{O}_{3}$ catalyst of $550^{\circ} \mathrm{C}$

\section{Effect of Retention Time}

Retention time is one of the important process parameters affecting the conversion efficiency of catalytic incineration. Spivey [3] indicated that the catalytic incineration requires retention time, in the range of $0.3 \sim 1.5$ seconds to decompose VOCs. In this study, the retention time was operated between 0.3 to $1.5 \mathrm{~s}$. The effect of retention time on the conversion efficiency of 1,2 -dichloroethane is shown in Fig. 4. The decreasing of retention time can cause the increasing of flow rate. The larger flow rate results in smaller oxidation rate since that mass transfer is limited. Fig. 4(a) shows that the conversion efficiency of $\mathrm{Fe}_{2} \mathrm{O}_{3}$ catalyst at incineration temperature increased to $525^{\circ} \mathrm{C}$ with the retention times in the range of $0.5 \sim 1.5 \mathrm{~s}$, the conversion efficiency of $\mathrm{Fe}_{2} \mathrm{O}_{3}$ catalyst was above 50\%. When $\mathrm{Fe}_{2} \mathrm{O}_{3}$ catalyst changes to $\mathrm{Pt}$ catalyst in the catalytic incineration at the retention times $0.5 \sim 1.5 \mathrm{~s}$, the conversion efficiency of Pt catalyst was above $80 \%$ in the incineration temperature $550^{\circ} \mathrm{C}$, as shown in Fig. 4(b).

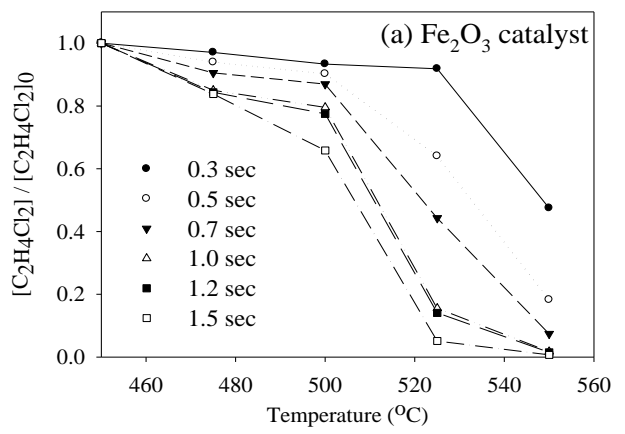

Fig. 4(a). Effect of different retention time of 1, 2-dichloroethane over the $\mathrm{Fe}_{2} \mathrm{O}_{3}$ catalyst.

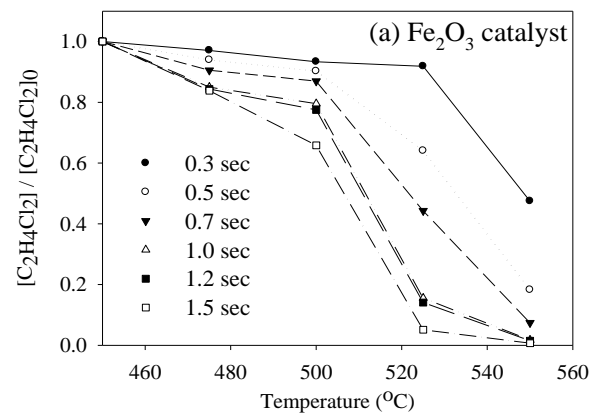

Fig. 4(b). Effect of different retention time of 1, 2-dichloroethane over the $\mathrm{Pt}$ catalyst.

\section{Effect of Incineration Temperature}

This study also evaluated different catalytic incineration temperatures of 1-2-dichloroethane from $450^{\circ} \mathrm{C}$ to $600^{\circ} \mathrm{C}$. In Fig. 5, the conversion efficiency of $\mathrm{Pt}$ and $\mathrm{Fe}_{2} \mathrm{O}_{3}$ catalysts at the incineration temperature of $475^{\circ} \mathrm{C}$ was not obvious. Fig. 5(a) shows the reaction with $\mathrm{Pt}$ catalyst became active while the temperature was increased to $500^{\circ} \mathrm{C}$, even with small retention time. In contrast, Fig. 5(b) shows obvious larger conversion efficiency of $\mathrm{Fe}_{2} \mathrm{O}_{3}$ catalyst at the incineration temperature of $525^{\circ} \mathrm{C}$. In addition, the conversion efficiency $(\eta)$ of Pt catalyst and $\mathrm{Fe}_{2} \mathrm{O}_{3}$ catalyst at $550^{\circ} \mathrm{C}$ was $66 \sim 99.8 \%$ and 53 99\%, respectively. In general, the conversion efficiency of 1-2-dichloroethane was increased with the increase of the temperature with these two catalysts.

\section{E. Kinetic Analysis of Arrhenius Equation}

The temperature dependence of kinetic parameter $k_{o b s}$ $(1 / \mathrm{sec})$ in Eq. (2) can also be described by the Arrhenius equation as follows:

$$
k_{o b s}=A \exp \left(-\frac{E a}{R T}\right)
$$

where:

$k_{\text {obs }}$ : kinetic parameter $(1 / \mathrm{min})$

$A$ : frequency factor $(1 / \mathrm{min})$

$E a$ : activation energy (kcal/mole)

$T$ : temperature $(\mathrm{K})$

$R$ : gas constant $\left(1.987 \times 10^{-3} \mathrm{kcal} /\right.$ mole $\left.\mathrm{K}\right)$

Integration of Eq. (2) yields an expression as follows:

$$
\ln k_{o b s}=\ln A-\frac{E a}{R T}
$$

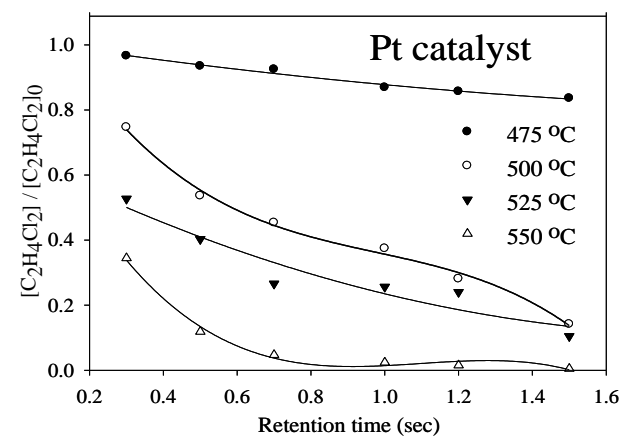

Fig. 5(a). Effect of temperature of 1, 2-dichloroethane over the Pt catalyst

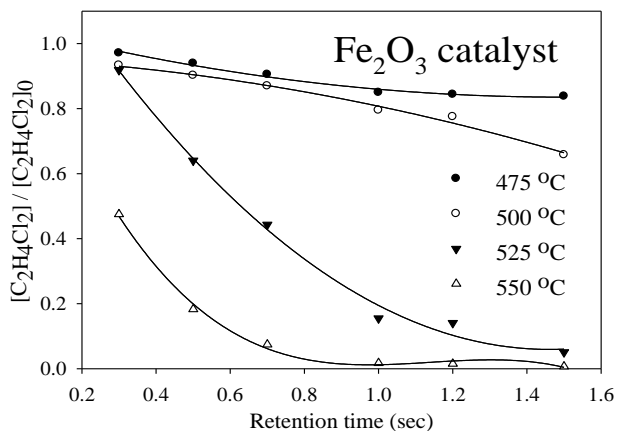

Fig. 5(b). Effect of temperature of 1, 2-dichloroethane over the $\mathrm{Fe}_{2} \mathrm{O}_{3}$ catalyst 


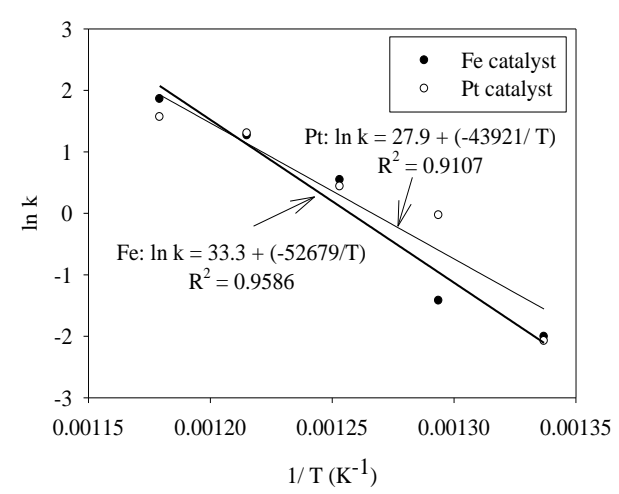

Fig. 6. Arrhenius plot showing two catalyst relationships for $1 /$ kobs with 1 , 2-dichloroethane

Based on Eq. (3), the linear expression can also be obtained by plotting the reciprocal degradation rate $\left(1 / k_{o b s}\right)$ as a function of the reciprocal of temperature $(1 / \mathrm{T})$. The values of $k_{\text {obs }}$ are shown in Fig. 6 with Pt catalyst and $\mathrm{Fe}_{2} \mathrm{O}_{3}$ catalyst for 1,2-dichloroethane. The fitting results in Fig. 6 seem well and the $\mathrm{R}^{2}$ value of $\mathrm{Pt}$ catalyst and $\mathrm{Fe}_{2} \mathrm{O}_{3}$ catalyst was 0.911 and 0.958 , respectively. The frequency factor (A) and the activation energy $(E a)$ can be evaluated by means of a lowest square/best fitting procedure by using Equation (2). The results show that the values of $\mathrm{A}$ and $E a$ for the catalytic conversion of 1,2-dichloroethane with $\mathrm{Pt}$ catalyst were roughly $27.9\left(\mathrm{sec}^{-1}\right)$ and $43.92(\mathrm{kcal} / \mathrm{mol})$, respectively. In addition, the values of $\mathrm{A}$ and $\mathrm{Ea}$ with the $\mathrm{Fe}_{2} \mathrm{O}_{3}$ catalyst were approximately $33.3\left(\mathrm{sec}^{-1}\right)$ and $52.68 \quad(\mathrm{kcal} / \mathrm{mol})$, respectively.

\section{CONCLUSION}

The oxy-dechlorination of 1,2-dichloroethane with excess oxygen was performed in laboratory scale tubular reactor with packed $\mathrm{Pt}$ and $\mathrm{Fe}_{2} \mathrm{O}_{3}$ catalyst. The results show that the degradation efficiency of 1,2-dichloroethane under various conditions followed the sequence: Pt catalyst $>$ Fe catalyst $>$ No catalyst in the incineration system. In this study, the decomposition products of 1,2-dichloroethane were identified as $\mathrm{C}_{2} \mathrm{H}_{4}, \mathrm{C}_{2} \mathrm{H}_{6}$ and $\mathrm{C}_{3} \mathrm{H}_{6}$. In general, the experimental data could be correlated well with the Arrhenius equation. The regression equation was identified as $\mathrm{K}=1.438 \times 10^{12} \exp (-22.10 \mathrm{~kJ} / \mathrm{RT})$ and $\mathrm{K}=3.004 \times 10^{14} \exp$ $(-26.51 \mathrm{~kJ} / \mathrm{RT})$ with $\mathrm{Pt}$ catalyst and $\mathrm{Fe}_{2} \mathrm{O}_{3}$ catalyst, respectively. Retention time is one of the important operation parameters affecting the catalytic oxidation rate since the higher flow rate in the reactor and smaller retention time will decrease the activity of catalyst to decompose the pollutants. In addition, the conversion efficiencies of $\mathrm{Pt}$ catalyst and $\mathrm{Fe}_{2} \mathrm{O}_{3}$ catalyst will be increased at any retention time while the incineration temperature was increased. Additionally, the optimum operation conditions of the $\mathrm{Pt}$ catalyst and $\mathrm{Fe}_{2} \mathrm{O}_{3}$ catalyst were determined as $0.7 \mathrm{~s} / 550^{\circ} \mathrm{C}$ and $1.0 \mathrm{~s} / 525^{\circ} \mathrm{C}$, respectively.

\section{ACKNOWLEDGMENT}

Financial support from the National Science Council, ROC, through Grant NSC101-2221-E-562-003-MY3 is gratefully acknowledged.

\section{REFERENCES}

[1] T. K. Tseng and H. Chu, J. Air Waste Manage, vol. 52, no. 10, pp. 174, 2002.

[2] N. R. Edward and A. C. Leigh, Chem. Eng. Progr. Vol. 89, no. 28, 1993.

[3] J. J. Spivey, Ind. Eng. Chem. Res. vol. 26, no. 11, pp. 2165, 1987.

[4] S. K. Agarwal, J. J. Spivey, J. B. Butt, Appl. Catal. A: General, vol. 82, no. 2 , pp. 259,1992

[5] G. M. Bickle, T. Suzuki, and Y. Mitarai, Appl. Catal. B: Environmental, vol. 4, no. 2-3, pp. 141, 1994.

[6] J. A. Rossin, M. M. Farris, Ind. Eng. Chem. Res. vol. 32, no. 6, pp. 1024, 1993.

[7] D. Pope, D. S. Walker, and R. L. Moss, Atmos. Environ. vol. 12, pp. $1921,1978$.

[8] H. Chu and W. T. Lee, Sci. Total Environ. vol. 209, no. 2-3, pp. 217, 1998.

[9] A. L. Barbosa, J. Herguido, and J. Santamaria, Catal. Today, vol. 64, no. 1-2, pp. 43, 2001.

[10] T. Sowade, F. W. Schutze, H. Berndt, and W. Grunert, Chem. Eng. Technol. vol. 27, no. 12, pp. 1277, 2004.

[11] Z. Li, K. Xie, W. Huang, and W. Reschetilowski, Chem. Eng. Technol. vol. 28, no. 7 , pp. 797, 2005

[12] M. T. Jan, S. Kureti, K. Hizbullah, and N. Jan, Chem. Eng. Technol. vol. 30 , no. 10 , pp. 1440,2007

[13] Z. Jia, Z. Liu, and Y. Zhao, Chem. Eng. Technol. vol. 30, no. 9, pp. 1221, 2007.

[14] K. M. Valkaj, A. Katovic, V. Tomasic, and S. Zrncevic, Chem. Eng. Technol. vol. 31, no. 3, pp. 398, 2008.

[15] H. Lin, Z. Huang, and W. Shangguan, Chem. Eng. Technol. vol. 31, no. 10, pp. 1433, 2008.

[16] Y. F. Y. Yao, J. Catal. vol. 87, no. 1, pp. 152.

[17] J. A. Rossin, Ind. Eng. Chem. Res. vol. 28, no. 10, pp. 1562, 1989.

[18] R. Burch and P. K. Loader, Appl. Catal. B: Environmental, vol. 5, no. 1-2, pp. 149, 1994.

[19] C. H. Wang, Chemosphere, vol. 55, no. 1, pp. 11, 2004

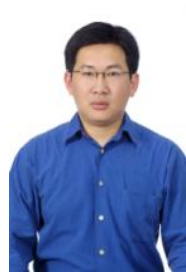

Chih-Ming Ma is an assistant professor in Department of Cosmetic Application and Management, St. Mary's Medicine Nursing and Management Colleg.The major field of study is in photocatalytic oxidation processes, nano particle preparation and characterization.

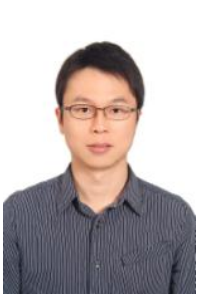

Gui-Bing Hong is an assistant professor in Department of Cosmetic Application and Management, St. Mary's Medicine Nursing and Management College. The major field of study is in physical-chemical treatment for wastewater and energy management.

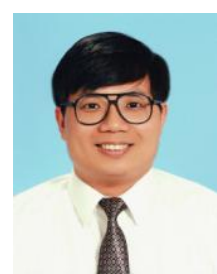

Chang-Tang Chang is a professor in Department of Environmental Engineering, National Ilan University, I-Lan, 260, Taiwan. The major field of study is in catalytic reaction, Air pollution treatment. 